\title{
Fumigant Toxicity of Camphor Against Tetranychus urticae Koch and Two Phytoseid Predators (Tetranychidae: Phytoseiidae)
}

\author{
E. M. Bakr \\ Plant Protection Research Institute, Agricultural Research Center, Egypt
}

\begin{abstract}
In attempt to find a new fumigant acaricide could be used in green houses, fumigant toxicity of camphor was studied against Tetranychus urticae Koch and two related predators i.e. Neoseiulus californicus (Mc.Gr.) and Phytoseiulus persimilis A. H. Camphor vapor gave a reasonable toxicity. Increasing temperature resulted in increasing toxicity as raise of temperature from 20 to $35^{\circ} \mathrm{C}$ decreased $\mathrm{LC}_{50}$ values from 3.28 to $2.61 \mathrm{mg} / 1$ and from 7.13 to $2.76 \mathrm{mg} / \mathrm{l}$ in case of mite adults and eggs, respectively. $N$. californicus and $P$. persimilis were more tolerant to camphor vapor with $\mathrm{LC}_{50}$ values 3.48 and $3.97 \mathrm{mg} / \mathrm{l}$ under $25^{\circ} \mathrm{C}$, respectively. Subjecting protonymphs to $\mathrm{LC}_{50}$ for $24 \mathrm{~h}$ resulted in significant shortage in the oviposition period and reduction in egg number reflecting reduction in finite rate of increase from 1.349 (non-treated mites) to 1.239 female/female/day.
\end{abstract}

Key Words: Camphor, Fumigant, Tetranychus urticae, Phytoseiulus persimilis, Neoseiulus californicus.

\section{INTRODUCTION}

Greenhouse plantations are usually attacked by many pests such as the two spotted spider mite Tetranychus urticae Foch as considered one of the most harmful pests. The loss is magnified in greenhoses for high density and usually valuable planted crops. High-density plantation also provides shelters for pests which may prevent the pesticides to reach all pest individuals. This leads to think about using natural fumigants for controlling pests in greenhouses, because of its safety and capability to reach every point in high density plantations. Fumigant toxicities of several volatile oils were previously proved by many authors such as, Stamopoulos, 1991; Weaver et al., 1994; DonPedro, 1996; Reddy and Singh, 1998; Sammataro et al., 1998 and Badawy et al. 2005. Camphor, which is an aromatic botanical material, is a good candidate to play an important role in this matter. It is a waxy white aromatic terpenoid material and its chemical formula is $\mathrm{C}_{10} \mathrm{H}_{16} \mathrm{O}$. It is found in the wood of Cinnamomum camphora, a large tree located in south east of Asia. Current work aimed to investigate the fumigant toxicity of camphor against T. urticae Koch as one of the main greenhouse pests and its two associated phytoseiid predators Phytoseiulus persimilis (A.-H.) and Neoseiulus californicus (Mc.G.).

\section{MATERIALS AND METHODS}

\section{Tested mites:}

Colonies of the spider mite $T$. urticae Koch and the two phytoseiid predators, $P$. persimilis and $N$. californicus were obtained from the Acarology Laboratory of Plant Protection Research Institute.

\section{Tested Camphor}

Camphor (Fig. 1) as white pure crystals was prepared by acetonic solution and applying small amounts of camphor.

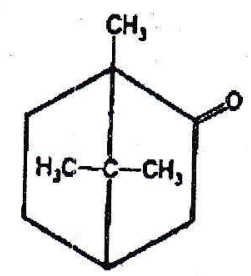

Fig.(1): Camphor structure.

\section{Fumigant acaricidal activity:}

The fumigant toxicity of camphor was evaluated against adult females, protonymphs and eggs of $T$. urticae. Also, the effect of camphor on afterward biological characters was investigated after subjecting red spider mites protonymphs to $\mathrm{LC}_{50}$ concentration. Airtight jars (5 liters size) were used as a test chamber.

Twenty newly ernerged adult females were transferred to the lower surface of mulberry disc (2.5 $\mathrm{cm}$ diameter). Placed separately on moist cotton wool in small dishes, slightly larger than the discs to reduce evaporation of water in the test jars. Dishes containing mites were fixed on the bottom of the test jars. Series amounts of camphor acetonic solution were dropped to clean Petri dishes using pipette then the dishes were left until acetone was evaporated leaving the intended amount of camphor as a pure layer. Each Petri dish containing the certain amount of camphor was also fixed on the bottom of the test jar. Concentrations were calculated as mg camphor per one liter jar space. Blank treatment was applied as a control. The jars were closed and incubated under 20,25 and $30 \pm 0.5^{\circ} \mathrm{C}$ constant temperature 
for $24 \mathrm{~h}$, then the mortality was estimated. The activity of camphor vapor was also examined against protonymphs using the same procedures then protonymphs were incubated under $25 \pm 0.5^{\circ} \mathrm{C}$ for $24 \mathrm{~h}$ and the mortality was assessed.

To investigate the ovicidal activity, ten adult females were transferred to mulberry leaf disc ( 2.5 $\mathrm{cm})$ placed on wet cotton wool in a Petri dish and left for 24 hours to deposit eggs then adults were removed. Discs carrying the eggs were placed separately on moist cotton wool in small dishes and subjected to series concentrations of camphor vapor for $24 \mathrm{~h}$, as described above. Treated eggs were incubated at $25 \pm 0.5{ }^{\circ} \mathrm{C}$ and $60 \% \pm 5 \mathrm{R}$.H. for six days till hatching and percentage of hatchability was determined.

Toxicity of camphor vapor was also examined against the two associated predators, $P$. persimilis and $N$. californicus. Large discs $(5 \mathrm{~cm})$ carrying sufficient amount of $T$. urticae eggs were prepared and placed on wet cotton wool in Petri dishes then ten predator adult females were transferred to each disc. Discs carried predators were subjected to series concentrations of camphor vapor as described above and incubated under constant temperature of $25 \pm 0.5^{\circ} \mathrm{C}$ for $24 \mathrm{~h}$, then the mortality was assessed.

Mortality percentages were corrected by Abbott's formula (1925). $\mathrm{LC}_{50}, \mathrm{LC}_{90}$ and slope values were calculated according to Finney (1971) using "LdP Line" ${ }^{18}$ software.

Changes in biological aspects of $T$. urticae were studied after subjecting protonymphs to $\mathrm{LC}_{50}$ concentration for $24 \mathrm{~h}$ as described above. Mortality was recorded and survived protonymphs were transferred separately, each to mulberry leaf disc and incubated at $25 \pm 0.5{ }^{\circ} \mathrm{C}$. The biological aspects were followed up until death. Data were analyzed using $\mathrm{T}$ test in order to examine the differences between treated-survived and non treated mites and finite rate of increase was calculated according to Birch (1948).

\section{RESULTS AND DISCUSSION}

Camphor vapor revealed reasonable initial fumigant toxicity against mite adult females (Table 1). Also, its fumigant toxicity increased along with increasing ambient temperature as initial $\mathrm{LC}_{50}$ values decreased gradually from 3.28 to $2.61 \mathrm{mg} / 1$ as temperature increased from 20 to $35^{\circ} \mathrm{C}$. Thus, on bases of $\mathrm{LC}_{90}, 4.81 \mathrm{mg} / 1$ camphor vapor concentration was able to kill $90 \%$ of mite population at $20^{\circ} \mathrm{C}$ while less concentration (3.86 $\mathrm{mg} / \mathrm{l})$ could kill the same at $35^{\circ} \mathrm{C}$. A little additional mortality was recorded when mites were observed one and two days after exposure which was reflected in a little decrease in $\mathrm{LC}_{50}$ and $\mathrm{LC}_{90}$ values.

Camphor ovicidal activity was also proved. As shown in table 2, eggs were more tolerant to camphor vapor than adults in low temperature, while, it had the same susceptibility as adults in high temperature. The impact of temperature appeared stronger in case of eggs than adults as the $\mathrm{LC}_{50}$ value decreased obviously from 7.13 to $2.76 \mathrm{mg} / 1$ when raising temperature from 20 to $35^{\circ} \mathrm{C}$. Similarly $\mathrm{LC}_{90}$ values decreased from 33.6 to $4.47 \mathrm{mg} / \mathrm{l}$.

Toxicity of camphor vapor was also studied against the two phytosiid predators $P$. persimilis and $\dot{N}$. californicus. T. urticae was more susceptible to camphor vapor than the two tested predators (Table 3). N. californicus was slightly tolerant to camphor vapor with $\mathrm{LC}_{50}$ value $3.48 \mathrm{mg} / \mathrm{l}$ and tolerance ratio 1.036 compared with $T$. urticae. $P$. persimilis was a little more tolerant with $\mathrm{LC}_{50}$ value $3.97 \mathrm{mg} / \mathrm{l}$ and tolerance ratio 1.182 .

Toxicity of camphor was also determined against protonymphs and $\mathrm{LC}_{50}$ of $2.93 \mathrm{mg} / \mathrm{l}$ was obtained. The effect of this concentration on the afterward biological aspects was studied. As shown in table 4 some changes were recorded in the biological aspect of treated-survived mites. The most ones were the significant decrease in the oviposition period and reduction in number of deposited eggs. Oviposition period was shortened from 14 in control to 9.25 days in treated mites, while deposited eggs were reduced

Table (1) Fumigant toxicity of camphor against $T$. urticae adult females under different temperatures.

\begin{tabular}{|c|c|c|c|c|}
\hline $\begin{array}{c}\text { Temp. } \\
\left({ }^{\circ} \mathrm{C}\right)\end{array}$ & $\begin{array}{l}\text { Days } \\
\text { after } \\
\text { treatment }\end{array}$ & $\begin{array}{l}\mathrm{LC}_{50} \\
\mathrm{mg} / \mathrm{l}\end{array}$ & $\mathrm{LC}_{90}$ & Slope \\
\hline \multirow{3}{*}{20} & 1 & $3.28(2.78-3.96)$ & 4.81 & 7.72 \\
\hline & 2 & $2.92(2.39-3.49)$ & 4.88 & 5.75 \\
\hline & 3 & $2.45(1.8-2.83)$ & 4.48 & 4.91 \\
\hline \multirow{3}{*}{25} & 1 & $3.36(3.00-3.78)$ & 4.47 & 10.33 \\
\hline & 2 & $3.22(2.88-3.58)$ & 4.37 & 9.61 \\
\hline & 3 & $3.11(2.70-3.61)$ & 4.54 & 7.83 \\
\hline \multirow{3}{*}{30} & 1 & $2.99(2.89-3.1)$ & 4.02 & 10.00 \\
\hline & 2 & $2.57(2.45-2.69)$ & 3.96 & 6.82 \\
\hline & 3 & $1.89(1.71-2.03)$ & 3.11 & 5.94 \\
\hline \multirow{3}{*}{35} & 1 & $2.61(2.49-2.72)$ & 3.86 & 7.52 \\
\hline & 2 & $2.25(2.13-2.36)$ & 3.37 & 7.32 \\
\hline & 3 & $2.17(2.05-2.27)$ & 3.16 & 7.82 \\
\hline
\end{tabular}


Table (2) Fumigant toxicity of camphor against

T. urticae eggs under different temperatures.

\begin{tabular}{llll}
\hline Temp. & LC $_{50}$ & LC $_{90}$ & Slope \\
\hline 20 & $7.13(5.32-15.6)$ & 33.601 & 1.904 \\
\hline 25 & $4.61(4.2-5.3)$ & 9.471 & 4.101 \\
\hline 30 & $3.15(2.58-3.94)$ & 5.35 & 5.557 \\
\hline 35 & $2.76(2.6-2.92)$ & 4.47 & 6.13 \\
\hline
\end{tabular}

Table (3): Toxicity of camphor vapors on $T$. urticae and the two predators, $P$. persimilis and $N$. californicus.

\begin{tabular}{|c|c|c|c|c|}
\hline Target mite & $\begin{array}{l}\mathrm{LC}_{50} \\
\mathrm{mg} / 1\end{array}$ & $\begin{array}{c}\text { Tolerance } \\
\text { ratio* }\end{array}$ & $\begin{array}{l}\mathrm{LC}_{90} \\
\mathrm{mg} / \mathrm{l} \\
\end{array}$ & Slope \\
\hline T: urticae & $3.36(2.995-3.78)$ & 1 & 4.47 & 10.33 \\
\hline N. californicus & $3.48(3.348-3.619)$ & 1.036 & 4.96 & 8.36 \\
\hline P.persimilis & $3.97(3.806-4.173)$ & 1.182 & 5.72 & 8.08 \\
\hline
\end{tabular}

Table (4) Effect of Camphor on the biological aspects of T. urticae.

\begin{tabular}{|c|c|c|c|c|c|c|c|c|c|}
\hline & \multicolumn{7}{|c|}{ Average duration in days } & \multirow[b]{2}{*}{$\begin{array}{l}\text { Eggs } \\
\text { Number }\end{array}$} & \multirow[b]{2}{*}{$\begin{array}{l}\text { Finite rate of } \\
\text { increase }\end{array}$} \\
\hline & $\begin{array}{c}\text { Pre- } \\
\text { treatment }\end{array}$ & $\begin{array}{l}\text { Q.Proto- } \\
\text { nymph }\end{array}$ & $\begin{array}{l}\text { Deuto- } \\
\text { nymph }\end{array}$ & $\begin{array}{l}\text { Q.Deuto - } \\
\text { Nymph }\end{array}$ & $\begin{array}{l}\text { Pre-ov. } \\
\text { Period }\end{array}$ & Ov. period & $\begin{array}{c}\text { Post-ov. } \\
\text { period }\end{array}$ & & \\
\hline $\begin{array}{l}\text { Treated } \\
\text { Control }\end{array}$ & 6.72 & $\begin{array}{l}0.83 \\
0.93\end{array}$ & $\begin{array}{l}1.38 \\
1.21\end{array}$ & $\begin{array}{l}1.31 \\
0.75\end{array}$ & $\begin{array}{l}1.58 \\
0.94\end{array}$ & $\begin{array}{c}9.25 \\
14\end{array}$ & $\begin{array}{c}0.88 \\
2.4\end{array}$ & $\begin{array}{l}30.75 \\
64.14\end{array}$ & $\begin{array}{l}1.239 \\
1.349\end{array}$ \\
\hline - & & 0.689 & 0.425 & $0.010^{* *}$ & $0.040^{* *}$ & $0.027^{* *}$ & $0.098^{*}$ & $0.001^{* * *}$ & \\
\hline
\end{tabular}

Q.: Quiescent, Ov.: oviposition, ${ }^{* *}$ : significance, P: probability of T value.

from 64.14 to 30.75 eggs per female. Mortality and overall changes in biological characters could be expressed in the finite rate of increase, as it was reduced from 1.349 to 1.239 female/female/day.

The efficacy of camphor against mites was expected under the shadow of previous studies. Camphor was used successfully against different pests such as the beetles, Sitophilus granarius, $S$. zeamais, Tribolium castaneum and Prostephanus truncates (Obeng-Ofori et al., 1998) and the rice weevil Sitophilus oryzae (Dayal et al., 2003). Pesticidal efficiency was proved against the cotton aphid, Aphis gossypii and the spider mite, Tetranychus urtica by Mousa 2003 as an emulsifiable concentrate. Camphor was also introduced in commercial product against Varroa jacobsoni (Rickli et al., 1991 and Mutinelli et al., 1993)

\section{REFEERENCES}

Abbott, W. S. 1925. A method of computing the effectiveness of an insecticide. J. Econ. Entomol., 18: 265-267.

Badawy, H.M.A.; Barakat, A. A.; Farrag, A. M. I. and Bakr, E. M. 2005. Biological activity of several essential oils against Tetranychus urticae Koch. Bull. Ent. Soc. Egypt, Econ. Ser., 31: 6978.

Birch, L. C. 1948. The intrinsic rate of natural increase of an insect population. J. Anim. Ecol., 17: 15-26.

Don-Pedro, K. N. 1996. Fumigant toxicity of citrus peel oils against adult and immature stages of storage insect pests. Pestic. Sci., 47: 213-223.

Finney, D. J. 1971. Probit Analysis. Cambridge Univ. Press., pp 333.

Mutinelli, F.; Irsara, A.; Ciemasco, S. and Piro, R. 1993. Control of varroosis by means of ApilifeVar in the detection tray. Apicoltore Moderno., 84 (3): 111-117.

Nachman, G. and Zemek, R. 2002 Interactions in a tritrophic acarine predator-prey metapopulation system III: Effects of Tetranychus urticae (Acari: Tetranychidae) on host plant condition. Exp. Appl. Acarol., 25: 27-42.

Mousa, G. M. 2003. Efficiency of camphor and citronella oils against the cotton aphid, Aphis gossypii and the spider mite Tetranychus urticae on eggplant. Assiut J. of Agric. Sci., 34(1) : 111118.

Obeng-Ofori, D.; Reichmuth, C, H.; Bekele, A. J. and Hassanali, A. 1998. Toxicity and protectant potential of camphor, a major component of essential oil of Ocimum kilimandscharicum against four stored product beetles. Int. J. Pest Manage., 44(4): 203-209.

Dayal, R.; Tripathi, R. and Renu, A. 2003. Comparative efficacy of some botanicals as protectant against Sitophilus oryzae in rice and its palatability. Annals of Plant Protection Sciences, 11(1): 160-162.

Reddy, A. V. and Singh, R. P. 1998. Fumigant toxicity of neem (Azadirachta indica A. Juss.) seed oil volatiles against pulse beetle, Callosobruchus maculatus Fab. (Col., Bruchidiae). J. Appl. Ent., 122: 607-611. 
Rickli, M.; Imdorf, A. and Kilchenmann, V. 1991. Treatment of varroa disease using compounds of essential oils. Apidologie, 22(4): 417-421.

Sammataro, D.; Drgrandi-Hoffman, G.; Needham, G. and Wardell, G. 1998. Some volatile plant oils as potential control agents for varroa mites (Acari: Varroidae) in honey bee colonies (Hymenoptra: Apidae). Am. Bee J., 138: 681-685.

Stamopoulos, D. C. 1991 Effect of four essential oil vapours on the oviposition and fecundity of Acanthoscelides obtecus (Say) (Coleoptra: Bruchidae): laboratory evaluation. J. stored Prod. Res., 27: 199-203.

Weaver D. K.; Dunkel, F. V.; Potter, R. C. and Ntezurubanza, L. 1994. Contact and fumigant efficacy of powdered and intact Ocimum canum Sims (Lamiales: Lamiaceae) against Zabrotes subfasciatus (Boheman) adults (Coleoptra: Bruchidae). J. Stored Prod. Res., 30: 243-252. 